Vera, A. M., Mantilla, J. C., \& Escobar, P. (2021). Antileishmanial activity of 29 daily sessions of intralesionalpentavalent antimony administration on Leishmania (Viannia)-infected BALB/c mice. Revista de Biología Tropical, 69(4), 1179-1188. https://doi.org/10.15517/rbt. v69i4. 47368

\title{
Anti-leishmanial activity of 29 daily sessions of intralesional-pentavalent antimony administration on Leishmania (Viannia)-infected BALB/c mice
}

\author{
Angélica María Vera ${ }^{1}$; (D) http://orcid.org/0000-0002-3352-2978 \\ Julio Cesar Mantilla2; (D) http://orcid.org/0000-0002-9834-5028 \\ Patricia Escobar *; (D) http://orcid.org/0000-0002-7527-2364
}

1. Centro de Investigación en Enfermedades Tropicales (CINTROP-UIS), Departamento de Ciencias Básicas, Universidad Industrial de Santander, Bucaramanga, Colombia; angelica_vera01@hotmail.com, pescobar@uis.edu.co (*Correspondence)

2. Departamento de Patología, Universidad Industrial de Santander (PAT-UIS), Bucaramanga, Colombia; jumantil@uis.edu.co

$$
\text { Received 19-IX-2021. Corrected 10-X-2021. Accepted 02-XI-2021. }
$$

\begin{abstract}
Introduction: Intralesional-pentavalent antimonials $\left(\mathrm{IL}_{-} \mathrm{Sb}^{\vee}\right)$ are recommended for simple cutaneous leishmaniasis (CL). Few treatment sessions (1-5) and drug volumes (1-5 ml each), relative to lesion size (LS), are recommended. There is not a validated IL-Sb ${ }^{\mathrm{V}}$ protocol using doses calculated as $\mathrm{mg} / \mathrm{kg}$ body weight and administered over a large number of IL-sessions, with small injection volumes.

Objective: The study aim was to determine the efficacy of different concentrations of IL-Sb ${ }^{\mathrm{V}}$ administered in 29 daily sessions of $100 \mu \mathrm{L}$ each, on CL infected mice.

Methods: Leishmania (Viannia) panamensis and L. (V.) braziliensis-infected mice $(\mathrm{N}=6)$ were treated with 150,50 , and $16.6 \mathrm{mgSb} / \mathrm{kg} /$ day x 29 days. Percentage of lesion area reduction, aesthetic and final (no lesions, no parasites) efficacy and effective dose $(\mathrm{ED})_{50}$ were determined. In vitro-Sb ${ }^{\mathrm{V}}$ activity against parasites was evaluated for both species.

Results: The $\mathrm{ED}_{50}$ values were 72.2 and 66.3 (at the end of treatment), 54.3 and 37.7 (15-days pt.), and 145.3 and 148.6 (60-days pt.) for each species, respectively. Differences were observed between Leishmania species at 15 -days pt., but not later. At 60 -day pt., $\mathrm{IL}_{-} \mathrm{Sb}^{\mathrm{V}}-150 \mathrm{mg}$ showed final cure rates of $66.6 \%$ for $L$. (V.) panamensis and $33.3 \%$ for $L$. (V.) braziliensis-infected mice. After 15 days pt., lesion reactivation was observed in some "aesthetically cured" mice. Glucantime was not active in in vitro assays.

Conclusions: The IL-Sb ${ }^{\mathrm{V}}$ use with a dose calculated as $\mathrm{mg} / \mathrm{kg}$ body weight and administered over a large number of IL-sessions, with small injection volumes each day could be effective against $L$. (V.) panamensis and $L$. (V.) braziliensis-CL infection. An appropriate $\mathrm{Sb}^{\mathrm{V}}$-dose (higher than $150 \mathrm{mg} / \mathrm{kg} / \mathrm{day}$ x less than 29 days) must be evaluated.
\end{abstract}

Key words: Glucantime; New World cutaneous leishmaniasis; intralesional drugs; Leishmania panamensis; Leishmania braziliensis.

New World cutaneous leishmaniasis (NW$\mathrm{CL})$ is the most common form of leishmaniasis in Latin America with an annual average of 56000 cases of cutaneous and mucosal leishmaniasis. It is produced by an intracellular protozoan parasite belonging to subgenus Viannia or Leishmania, transmitted to humans and reservoirs by infected female sand-flies 
of the genus Lutzomyia (Pan American Health Organization, 2018). Symptomatic NW-CL is characterized by skin lesions, such as papules, nodules, or ulcerative volcano-like lesions, with varied outcomes, in terms of lesion number and size, scar type, disability, spontaneous healing, and destructive mucosal inflammation (Bailey et al., 2017).

Pentavalent antimonials $\left(\mathrm{Sb}^{\mathrm{V}}\right.$, Glucantime, and Pentostam) remain the standard treatment for all forms of leishmaniasis in some countries (Burza, et al.,2018). They are administered parentally in $10-30$ doses of $20 \mathrm{mg} / \mathrm{kg} /$ day, depending on the clinical manifestations. Mild to severe side effects, including arthralgia, myalgia, cardiotoxicity, nephropathy, and pain during intramuscular administration, are observed (Burza et al., 2018; Goto \& Lindoso, 2010). In some regions endemic for visceral leishmaniasis, such as Bihar, in Eastern India, therapeutic failure (TF) can be observed in up to $65 \%$ of cases, while estimates of antimonial TF rates on NW-CL range from 15-32\% (Castro, et al.,2017; Sundar et al., 2000). In cases with simple CL (single or a few lesions, up to $900 \mathrm{~mm}^{2}$ ), pregnant women, and patients with kidney, heart disease, or other concomitant diseases, local/topical treatments, such as cryotherapy, localized heat, intralesional drugs, or topical application of semisolid formulations directly onto the lesion are alternative therapies (Burza et al., 2018).

Intralesional (IL)- $\mathrm{Sb}^{\mathrm{V}}$ treatment is widely used in treatment of Old World-CL, and is applied alone, or in combination with cryotherapy. Further, intralesional (IL)-Sb ${ }^{\mathrm{V}}$ therapy is recommended for simple NW-CL cases, where lesions do not involve the face or joints (PAHO, 2018). Intralesional- $\mathrm{Sb}^{\mathrm{V}}$ injection is easily administered by trained staff, does not require hospitalization, can be given at a low dose, and results in less systemic drug absorption, side effects, and treatment costs; 1-5 sessions of intradermal IL-Sb ${ }^{\mathrm{V}}$ injections, with 1-5 ml per session, at the border or base of the CL-lesion every 3-7 days are recommended (PAHO, 2018). The overall clinical efficacy of $\mathrm{IL}_{-} \mathrm{Sb}^{\mathrm{V}}$ using an injectable Glucantime solution (the same one used for intramuscular route treatment) is reported as 75 to $77 \%$ (de Oliveira Duque et al., 2019; Oliveira-Neto et al., 1997). In Bolivian patients with CL, three or five sessions of 2-3 ml each $\left(650 \mu \mathrm{g} \mathrm{Sb}{ }^{\mathrm{V}}\right.$ per $\mathrm{mm}^{2}$ ), every other day resulted in cure rates from 57 to $73 \%$ at 6 months (Soto et al., 2016). Overall TF was $30 \%$ (like parenteral $\mathrm{Sb}^{\mathrm{V}}$ ) and no recurrences were recorded in cured patients for $\geq 6$ months (de Oliveira Duque et al., 2019; Oliveira-Neto et al., 1997). There is not a validated IL-SbV protocol using doses calculated as $\mathrm{mg} / \mathrm{kg}$ body weight and administered over a large number of IL-sessions, with small injection volumes in humans. In addition, there is not an IL-Sb ${ }^{\mathrm{V}}$ protocol available as a positive control for NW-CL intralesional drug discovery able to demonstrate both efficacy and some $\mathrm{Sb}^{\mathrm{V}}$-IL risks such as lesion reactivation and $\mathrm{TF}$ on experimental models.

The present study aim was to determine the efficacy of different concentrations of IL$\mathrm{Sb}^{\mathrm{V}}$ (Glucantime) administered in 29 daily sessions of $100 \mu \mathrm{L}$ each, on mice infected with two common NW-CL species, $L$. (V.) panamensis and L. (V.) braziliensis.

\section{MATERIALS AND METHODS}

Drugs and reagents: Meglumine antimoniate, Glucantime ${ }^{\circledR}$ (Sanofi-Aventis, Brazil; lot 357345) was kindly donated by the Secretary of Health of Santander, Colombia. One bottle of Glucantime contained $1.5 \mathrm{~g}$ of meglumine antimoniate (405 $\mathrm{mg}$ of $\left.\mathrm{Sb}^{\mathrm{V}}\right)$. Schneider's insect medium, RPMI medium, and heat inactivated FBS (hiFBS) were from Gibco (Grand Island, NY, USA).

Parasites and cells: Promastigotes of $L$. (V.) panamensis (MHOM/PA/71/LS94) and $L$. (V.) braziliensis (MHOM/BR/75/M2903) were maintained in Schneider's medium plus 10 $\%$ hiFBS at $28{ }^{\circ} \mathrm{C}$. Human leukaemia THP-1 cells (ATCC, USA) were cultured in RPMI 1640 medium plus $10 \%$ hiFBS at $37{ }^{\circ} \mathrm{C}$ in a $5 \% \mathrm{CO}_{2} / 95 \%$ air mixture. THP-1 cells were transformed to adherent cells using $40 \mathrm{ng} / \mathrm{ml}$ 
phorbol 12-myristate 13 -acetate for $48 \mathrm{~h}$, and these macrophages infected with stationaryphase promastigotes at a cell: parasite ratio of 1:5 for $24 \mathrm{~h}$ at $32{ }^{\circ} \mathrm{C}$. The percentage of infection was determined microscopically by Giemsa staining. Axenic amastigotes were obtained from late-phase promastigotes after 8 days of transformation by progressive changes of temperature (from 27 to $32{ }^{\circ} \mathrm{C}$ ) and $\mathrm{pH}$ (from $\mathrm{pH}$ 7.0 to 5.5). The Leishmania species used were susceptible to miltefosine, pentamidine and ketoconazole (Neira, et al., 2019a).

Animals, ethics: Female and male BALB/c mice (10-12 weeks of age) were supplied by the National Health Institute (Bogotá, Colombia). Mice were housed with a $12 \mathrm{~h}$ light/dark cycle, at $23{ }^{\circ} \mathrm{C}, 55 \% \pm 5 \%$ relative humidity, with access to water and food pellets ad libitum. Studies were approved by the UISEthics Committee (CIENCI, Code 17-2017). Animals were anesthetized by intraperitoneal injection of a ketamine/xylazine cocktail and euthanized by cervical dislocation.

Anti-leishmanial activity in vivo: Mice were infected by subcutaneous injection in the shaven rump with $5 \times 10^{5}$ stationary-phase parasites. When lesion size (LS) was in the range $40-42 \mathrm{~mm}^{2}$ (8 weeks after infection), mice were randomly allocated into four groups $(\mathrm{N}=6$ per group); different concentrations of $\mathrm{Sb}^{\mathrm{V}}$ (150, 50 , and $16.6 \mathrm{mg} \mathrm{Sb} / \mathrm{kg}$ body weight /day) and vehicle $(0.9 \%$ saline solution $)(100 \mu \mathrm{L})$ were injected intralesionally (IL) for 29 days. Doses of $\mathrm{Sb}^{\mathrm{V}}$ were calculated for mice using mean body weight $(27 \mathrm{~g})$, containing $4.1,1.4$, and 0.4 $\mathrm{mg} \mathrm{Sb}^{\mathrm{V}}$ per mouse and a total of 117.5, 39.2, and $13.9 \mathrm{mg} \mathrm{Sb} /$ mouse over 29 days. Lesion size was measured weekly using a digital calliper and lesion area $\left(\mathrm{mm}^{2}\right)$ calculated (Neira et al., 2019a). Follow-up period was determined in a preliminary experiment (Appendix 1). Briefly, Leishmania infected mice $(\mathrm{N}=1$ per species) were treated with IL-SbV $-150 \mathrm{mg} / \mathrm{kg} /$ day $\times 29$ days and sacrificed 15, 22, 29, and 42-days post-treatment. The chosen follow-up time was 60 days' post treatment (pt.).
At the end of the experiment, animals were sacrificed, and smears (imprints) prepared from lesions fixed in methanol and stained with Giemsa for detection and calculation of parasites by microscopy. Additionally, lesion samples were collected and processed for histopathological examination. Amastigote number per microscopic field $(400 \times)$ was semiquantitatively scored [No parasites $=0$, scarce $=1-5(+)$, moderate $=6-10(++)$, abundant $>11$ $(+++)$ parasites)] and percentage LS reduction (LSred) calculated (Neira, et al.,2019b). Aesthetic efficacy $(\mathrm{eE})$ was calculated as $(\mathrm{N}$ mice with $>75 \%$ of LSred $/ 6$ mice $) \times 100$, and final efficacy (fE) as ( $\mathrm{N}$ mice with both $100 \%$ of LSred and no parasites $/ 6) \times 100$. Reactivation was defined as the appearance of a new lesion in a previously aesthetically $100 \%$ healed site. Mean effective dose (ED) $)_{50}$ (dose of $\mathrm{Sb}^{\mathrm{V}}$ able to reduce LS by $50 \%$ ) with $95 \%$ confidence interval $(95 \% \mathrm{CI})$ was calculated by sigmoidal regression using MsxlfitTM software.

Adverse effects: Mice weight was measured weekly using a digital balance. Skin irritation was registered by visual inspection and signs of irritation at application sites classified from $0=$ no irritation to $4=$ severe irritation.

Histopathological analysis: Samples were fixed with $10 \%$ neutral formalin, embedded in paraffin, and sectioned into $5 \mu \mathrm{m}$ thick sections using a microtome. Dewaxed slices were stained with haematoxylin-eosin and examined by microscopy. Histopathological parameters and parasites were semi-quantified and scored as follows: -, absent; +, mild; ++, moderate; and +++ , severe (Neira et al., 2019b).

In vitro assay: Promastigotes and axenic amastigotes were incubated with serial 1:3 dilutions of Glucantime (33.3 to $900 \mu \mathrm{g} / \mathrm{ml}$ ) for $72 \mathrm{~h}$ at 27 and $32{ }^{\circ} \mathrm{C}$, respectively (Gupta et al., 2001). Control cells were incubated in culture medium. Drug activities were assessed using a resazurin colorimetric test. Absorbance values were measured using a Synergy H1 microplate reader at 570 and $600 \mathrm{~nm}$. For 
intracellular parasites, infected THP-1 cells were treated with Glucantime for 5 days, at $32{ }^{\circ} \mathrm{C}$ (Neira et al., 2019a). Parasite growth inhibition was determined by counting infected and non-infected cells on Giemsa-stained slides by microscopy. $\mathrm{IC}_{50}$ values were calculated as described for $\mathrm{ED}_{50}$.

Statistical analysis: Differences were analyzed using the Student's t-test. P values $\leq$ 0.05 were considered statistically significant. Area under the curve values were calculated for comparisons of $\mathrm{Sb}^{\mathrm{V}}$ dose-response effects using GraphPad Prism software, version 6.0 for Windows and two-way ANOVA and Sidak post-hoc method.

\section{RESULTS}

Efficacy of treatment with $\mathrm{IL}_{-} \mathrm{Sb}^{\mathrm{V}} \mathbf{- 1 5 0}$ $\mathbf{m g} / \mathbf{k g} \times 29$ : For $L$. (V.) panamensis infection,

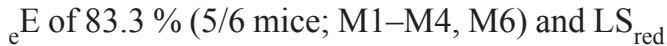
values of $87.0-100 \%$ were observed both at the end of treatment and 15-days pt. At 60-days pt., LS reactivation ( $\mathrm{Re}$ ) was observed in mouse M6 (Table 1, Fig. 1). Therapeutic failure was also observed in mouse $\mathrm{M} 5_{\text {failure }}$. At the end of treatment and until 43-day pt., M5 $5_{\text {failure }}$ showed $\mathrm{LS}_{\text {red }}$ of almost $50 \%$; however, a subsequent increase of LS by almost 8 times was observed (Table 1). In conclusion, 29 doses of IL$\mathrm{Sb}^{\mathrm{V}}-150 \mathrm{mg}$ induced a $\mathrm{E}$ value of $66.6 \%$ in $L$. (V.) panamensis-infected mice.

For L. (V.) braziliensis infected mice, an e value of $83.3 \%$ (5/6 mice, M1, M2, M4, M5, M6) and $\mathrm{LS}_{\text {red }}$ from 80.9 to $100 \%$ were observed both at the end of treatment and at 15 -days pt. At 50-day pt., lesion reactivation was detected in mice M4, M5, and M6. Additionally, mouse M2, an aesthetically cured animal, tested positive for parasites in biopsy samples (Table 2, Fig. 2). Mouse M3 showed a slight decrease in LS at 15 days pt. and a complete aesthetic response, without observable parasites, at the end of the experiment. Consequently, ${ }_{\mathrm{f}} \mathrm{E}$ was $33.3 \%$.

All non-cured mice showed abundant $(+++)$ intra and extracellular amastigotes in CL-lesion samples.

None of the mice treated with 29 doses of $\mathrm{IL} \mathrm{Sb}^{\mathrm{V}}$ showed body weight loss, skin irritation, or any signs of pain or loss of well-being.

Efficacy of lower doses (IL-Sb ${ }^{\mathrm{V}}-\mathbf{5 0} \mathrm{mg}$ / kg $x \quad 29$ days and IL-Sb ${ }^{\mathrm{V}} \mathbf{- 1 6 . 6} \mathrm{mg} / \mathrm{kg} x$ 29 days): At 15-day pt., $L$. (V.) panamensis infected mice M4, M5, and M6 treated with IL-Sb ${ }^{\mathrm{V}}-50 \mathrm{mg}$, displayed considerable

TABLE 1

Efficacy of 29-doses of IL-SbV at $150 \mathrm{mg} / \mathrm{kg} /$ day in mice infected with $L$. (V.) panamensis

\begin{tabular}{|c|c|c|c|c|c|c|c|c|c|c|c|c|c|}
\hline \multirow{4}{*}{ Mice } & \multirow{4}{*}{$\begin{array}{c}\text { Before } \\
\mathrm{mm}^{2}\end{array}$} & \multicolumn{12}{|c|}{ 29-doses-IL-SbV-150 mg on L. (V.) panamensis infected mice } \\
\hline & & \multicolumn{3}{|c|}{ end treatment } & \multicolumn{3}{|c|}{ 15-day pt. } & \multicolumn{6}{|c|}{ 60-day pt. } \\
\hline & & \multirow{2}{*}{$\mathrm{mm}^{2}$} & \multirow{2}{*}{$\begin{array}{c}\mathrm{LS}_{\mathrm{red}} \\
(\%)\end{array}$} & \multirow{2}{*}{$\begin{array}{c}e^{E} \\
(\%)\end{array}$} & \multirow{2}{*}{$\mathrm{mm}^{2}$} & \multirow{2}{*}{$\begin{array}{c}\mathrm{LS}_{\text {red }} \\
(\%)\end{array}$} & \multirow{2}{*}{$\begin{array}{l}\mathrm{e}^{\mathrm{E}} \\
(\%)\end{array}$} & \multirow{2}{*}{$\mathrm{mm}^{2}$} & \multirow{2}{*}{$\begin{array}{c}\mathrm{LS}_{\text {red }} \\
(\%)\end{array}$} & \multirow{2}{*}{$\begin{array}{c}\mathrm{e}^{\mathrm{E}} \\
(\%)\end{array}$} & \multicolumn{2}{|c|}{ Parasites } & \multirow[t]{2}{*}{${ }_{f} E$} \\
\hline & & & & & & & & & & & imprints & biopsies & \\
\hline M1 & 36.6 & 3.5 & 90.5 & \multirow{6}{*}{83.3} & 0 & 100 & \multirow{6}{*}{83.3} & 0 & 100 & \multirow{6}{*}{66.6} & - & - & \multirow{6}{*}{66.6} \\
\hline M2 & 35.4 & 0 & 100 & & 0 & 100 & & 0 & 100 & & - & - & \\
\hline M3 & 32.5 & 0 & 100 & & 0 & 100 & & 0 & 100 & & - & - & \\
\hline M4 & 45.9 & 6.2 & 86.6 & & 0 & 100 & & 0 & 100 & & - & - & \\
\hline M5 & 50.3 & 35.2 & 29.9 & & 19.6 & 61.0 & & 153.2 & 0 & & +++ & +++ & \\
\hline M6 & 46.7 & 3.1 & 93.3 & & 0 & 100 & & 31.6 & $\mathrm{Re}^{\mathrm{b}}$ & & +++ & +++ & \\
\hline SS & 13.8 & 28.7 & 0 & $\mathrm{ND}^{\mathrm{c}}$ & 30.1 & 0 & ND & 46.5 & 0 & ND & +++ & +++ & ND \\
\hline
\end{tabular}

The table shows details of individual lesion size (LS) before and at the end of treatment and at 15 and 60 days post treatment (pt.) $(\mathrm{N}=6)$. Parasite loads were scored at the end of treatment. $\mathrm{LS}_{\mathrm{red}}$ : lesion size reduction; ${ }_{\mathrm{e}} \mathrm{E}$ : aesthetic efficacy; $\%_{\mathrm{e}} \mathrm{E}$ : percentage of mice with $\mathrm{LS}_{\text {red }}$ between $\left.75-100 \%\right) ; \mathrm{E}$, final efficacy: with a complete aesthetic and parasite response; SS: saline solution (a representative control mouse); Re: reactivation; ND: not determined. 


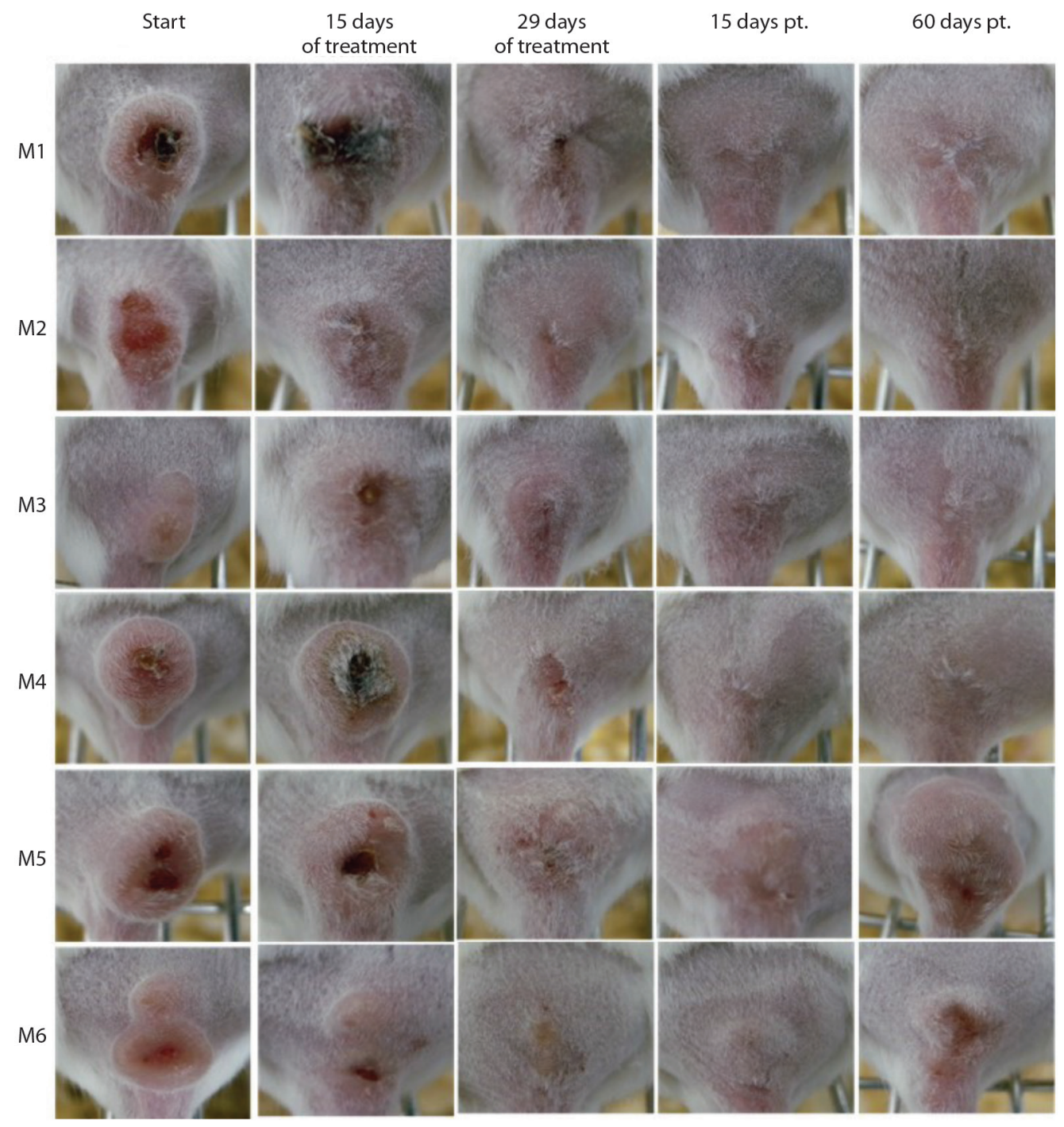

Fig. 1. Response of mice infected with L. (V.) panamensis to IL-Sb ${ }^{\mathrm{V}}-150 \mathrm{mg} / \mathrm{kg} / \mathrm{day}$ x 29. Photographs of CL lesions in mice M1-M6 at the beginning, 15 days and at the end of treatment (29 days); and at 15 and 60 days pt.

improvement $\left(\mathrm{LS}_{\mathrm{red}}\right.$ 89.5-100\%) (Appendix 2, Appendix 3) and stable effects were also observed in mice M1, M2, and M3 (LS 43.7-58.4\%); however, at 60-day pt., reactivation or increase of LS was observed. In mice treated with IL-SbV $-16.6 \mathrm{mg}, \mathrm{LS}_{\text {red }}$ values from 0 to $51.6 \%$ were observed both at the end of treatment and 15 days pt.; however, at the end of the experiment, ${ }_{\mathrm{f}} \mathrm{E}$ was zero and abundant
$(+++)$ parasites were observed by microscopy in imprint smears and biopsies (Appendix 2, Appendix 4).

For L. (V.) braziliensis infected mice, IL$\mathrm{Sb}^{\mathrm{V}}$-50mg treatment induced $\mathrm{LS}_{\text {red. }}$ of 80-100 $\%$ in mice M2 and M4-M6 at 15 days pt.; however, reactivation occurred in two of these mice (M2 and M6) and there was an increase of LS in another (M4) with parasites present in all of 


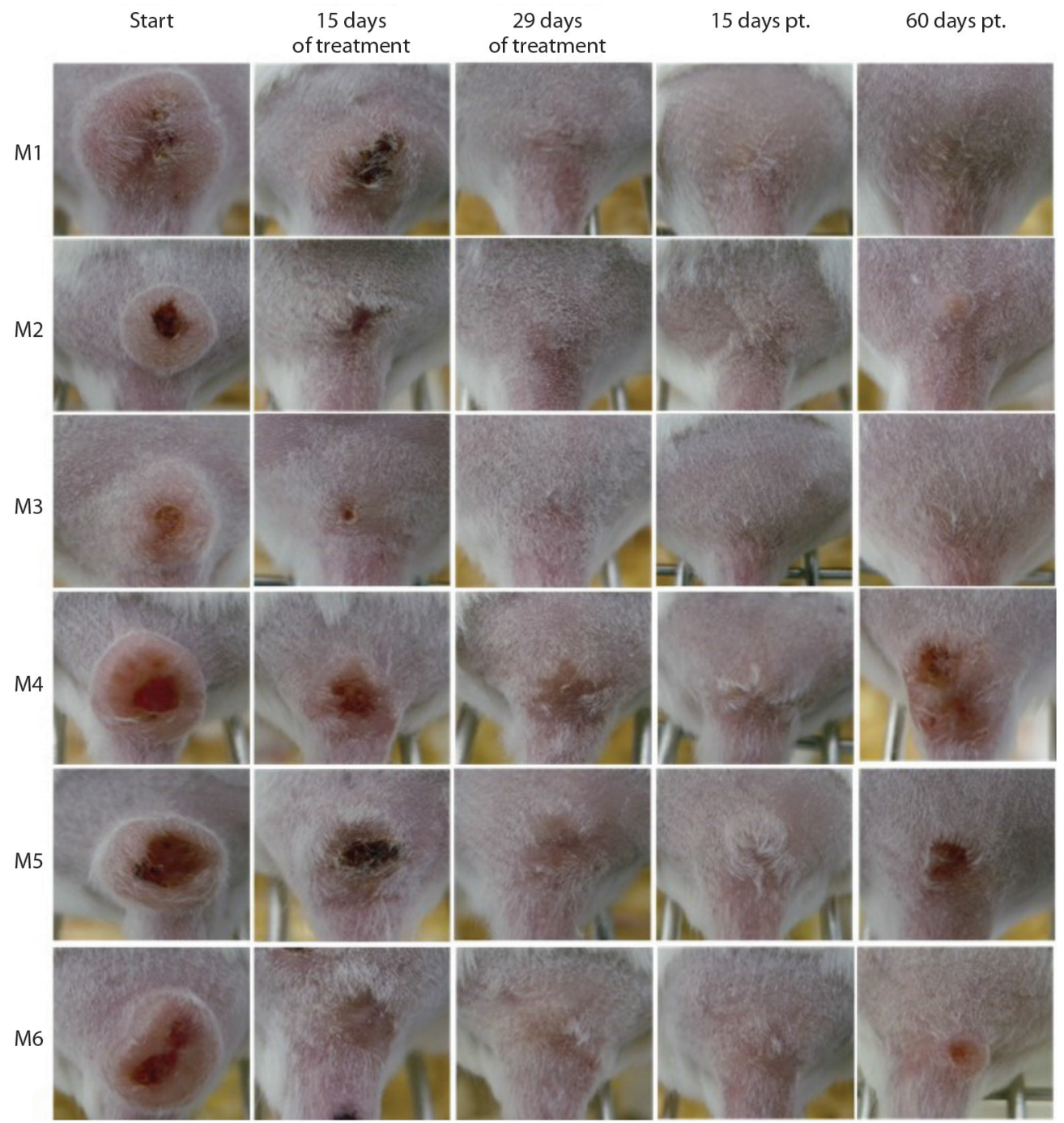

Fig. 2. L. (V.) braziliensis -infected mice response to IL-Sb ${ }^{\mathrm{V}}-150 \mathrm{mg} / \mathrm{kg} / \mathrm{day} \times 2$. Photographs of CL lesions in mice M1-M6 at the beginning, 15 days and at the end of treatment (29 days); and at 15 and 60 days pt.

them, including M5 (Appendix 5, Appendix 6). Treatment with IL-SbV $-16.6 \mathrm{mg}$ induced a $\mathrm{LS}_{\text {red }}$ of $87.2 \%$ in one mouse (M6) at 15 days pt.; however, TF occurred at 60-day pt. Parasites were observed in lesions from all treated mice by microscopy (Appendix 5, Appendix 7).

Cutaneous leishmaniasis lesions after relapse (Re): Mouse $\mathrm{M}_{\mathrm{Re}}$ treated with IL$\mathrm{Sb}^{\mathrm{V}}-150 \mathrm{mg}$ and mice $\mathrm{M} 4_{\mathrm{Re}}$ and $\mathrm{M} 6_{\mathrm{Re}}$ treated with IL-Sb ${ }^{\mathrm{V}}-50 \mathrm{mg}$ after infection with $L$. (V.) panamensis had new lesions of LS of 31.6, 11.6 , and $3.5 \mathrm{~mm}^{2}$, respectively, at the end of the experiment. Mice $\mathrm{M} 4_{\mathrm{Re}}-\mathrm{M} 6_{\mathrm{Re}}$, treated with IL-Sb $-50 \mathrm{mg}$ and $\mathrm{M} 2_{\mathrm{Re}}$ and $\mathrm{M} 6_{\mathrm{Re}}$, with IL-SbV ${ }^{\mathrm{V}}-16.6 \mathrm{mg}$, following $L$. (V.) braziliensis infection, relapsed with new lesions of LS 30.6, $11.9,8.6,7.8$, and $20.0 \mathrm{~mm}^{2}$, respectively, at the end of the experiment. Lesions reappeared at the inoculation site and began as papules, 
TABLE 2

Efficacy of 29 doses of IL-SbV at $150 \mathrm{mg} / \mathrm{kg}$ in mice infected with L. (V.) braziliensis

\begin{tabular}{|c|c|c|c|c|c|c|c|c|c|c|c|c|c|}
\hline \multirow{4}{*}{ Mice } & \multirow{4}{*}{$\begin{array}{l}\text { Before } \\
\left(\mathrm{mm}^{2}\right)\end{array}$} & \multicolumn{12}{|c|}{ 29-doses-IL-Sb ${ }^{\mathrm{V}}-150 \mathrm{mg}$ on $L$. (V.) braziliensis infected mice } \\
\hline & & \multicolumn{3}{|c|}{ end of treatment } & \multicolumn{3}{|c|}{ 15-day pt. } & \multicolumn{6}{|c|}{ 60-day pt. } \\
\hline & & \multirow[b]{2}{*}{$\mathrm{mm}^{2}$} & \multirow[b]{2}{*}{$\begin{array}{c}\mathrm{LS}_{\text {red }} \\
(\%)\end{array}$} & \multirow[b]{2}{*}{$\begin{array}{c}\mathrm{E} \\
(\%)\end{array}$} & \multirow[b]{2}{*}{$\mathrm{mm}^{2}$} & \multirow{2}{*}{$\begin{array}{c}\mathrm{LS}_{\text {red }} \\
(\%)\end{array}$} & \multirow[b]{2}{*}{$\begin{array}{c}\mathrm{e}^{\mathrm{E}} \\
(\%)\end{array}$} & \multirow[b]{2}{*}{$\mathrm{mm}^{2}$} & \multirow[b]{2}{*}{$\begin{array}{c}\mathrm{LS}_{\text {red }} \\
(\%)\end{array}$} & \multirow[b]{2}{*}{$\begin{array}{c}\mathrm{e}^{\mathrm{E}} \\
(\%)\end{array}$} & \multicolumn{2}{|c|}{ Parasites } & \multirow[t]{2}{*}{${ }_{f}^{E}$} \\
\hline & & & & & & & & & & & $\begin{array}{c}\mathrm{Im} \\
\text { prints }\end{array}$ & biopsies & \\
\hline M1 & 55.9 & 0 & 100 & \multirow{6}{*}{83.3} & 0 & 100 & \multirow{6}{*}{83.3} & 0 & 100 & \multirow{6}{*}{50} & - & - & \multirow{6}{*}{33.3} \\
\hline M2 & 34.9 & 0 & 100 & & 0 & 100 & & 0 & 100 & & - & ++ & \\
\hline M3 & 14.5 & 23.2 & 0 & & 10.4 & 28.6 & & 0 & 100 & & - & - & \\
\hline M4 & 32.8 & 6.28 & 80.9 & & 0 & 100 & & 30.6 & $\mathrm{Re}^{\mathrm{b}}$ & & +++ & +++ & \\
\hline M5 & 35.7 & 0 & 100 & & 0 & 100 & & 11.9 & $\mathrm{Re}$ & & +++ & +++ & \\
\hline M6 & 43.1 & 0 & 100 & & 0 & 100 & & 8.7 & $\mathrm{Re}$ & & +++ & +++ & \\
\hline $\mathrm{SS}^{\mathrm{a}}$ & 13.65 & 49.64 & 0 & $\mathrm{ND}^{\mathrm{c}}$ & 57.8 & 0 & ND & 113.5 & 0 & ND & +++ & +++ & ND \\
\hline
\end{tabular}

The table shows details of individual lesion size (LS) before and at the end of treatment and at 15 and 60 days' post treatment (pt.) $(\mathrm{N}=6)$. Parasite loads were scored at the end of treatment. $\mathrm{LS}_{\text {red }}$ : lesion size reduction; ${ }_{\mathrm{e}} \mathrm{E}$ : aesthetic efficacy; \% $\mathrm{E}$ : percentage of mice with $\mathrm{LS}_{\text {red }}$ between $\left.75-100 \%\right) ; \mathrm{f}$, final efficacy: with a complete aesthetic and parasite response; SS: saline solution (a representative control mouse); Re: reactivation; ND: not determined.

that gradually evolved into nodules with raised edges. In some cases, they presented as typical clean, pink ulcers, with granular tissue, and rounded with regular and raised edges.

Dose response activities of $\mathrm{Sb}^{\mathrm{V}}$ : The mean effective dose $(\mathrm{ED})_{50}$ values for $L$. $(V$. $)$ panamensis and L. (V.) braziliensis infected mice were 33.99 (CI, 18.89-61.14) $\mathrm{mg}$ and 36.96 (CI, 17.87-76.45) $\mathrm{mg}$ at the end of treatment; 28.62 (CI, 16.53-49.55) $\mathrm{mg}$ and 12.40 (CI, 4.41-34.91) $\mathrm{mg}$ at 15 days pt.; and 142.6 (CI, 57.56-353.3) $\mathrm{mg}$ and 157.8 (CI, 58.99421.9) $\mathrm{mg}$ at 60 pt., respectively. At 43 days pt., IL-Sb ${ }^{\mathrm{V}}$ was more active in mice infected with $L$. (V.) braziliensis than $L$. (V.) panamensis $(\mathrm{P}<0.001)$; however, no difference was observed at the end of the experiment (60 days pt.). No significant differences were detected in the response to $\mathrm{IL}_{-} \mathrm{Sb}^{\mathrm{V}}$ between mice infected with the two species of Leishmania based on analysis of LS or area under the curve values for lesion changes after treatment with at 150 , 50 , or $16.6 \mathrm{mg} / \mathrm{kg} /$ day IL-Sb ${ }^{\mathrm{V}} \times 29$.

Histopathological characteristics: Responders (cured) mice (M1-M4 for L. (V.) panamensis; M1 and M3 for $L$. (V.) braziliensis) showed none to mild changes in the epidermis and dermis (Appendix 8, Appendix 9, Appendix 10). In contrast, $M 5_{\text {failed }}$ or $M 6_{\mathrm{Re}}$ for $L$. (V.) panamensis, $\mathrm{M} 4_{\mathrm{Re}}-\mathrm{M} 6_{\mathrm{Re}}$ for L. (V.) braziliensis, and negative control mice presented with severe inflammatory infiltrates, comprising lymphocytes, neutrophils, macrophages, and giant cells. Some mice presented with severe acanthosis and moderate spongiosis and necrosis (Appendix 8).

In vitro drug activity: Based on $\mathrm{IC}_{50}$ values, $\mathrm{Sb}^{\mathrm{V}}$ was inactive against all live forms of parasites evaluated, since $\mathrm{IC}_{50}$ values were $>900 \mu \mathrm{gSb}^{\mathrm{V}} / \mathrm{ml}$ for both Leishmania strains.

\section{DISCUSSION}

In this work, we evaluated the responses of CL-infected mice to Glucantime, administered over a large number of IL-sessions, with small injection volumes each day (e.g., not until lesions blanched) and $\mathrm{Sb}^{\mathrm{V}}$ regimens calculated by body weight $(\mathrm{kg})$, instead of LS $\left(\mathrm{mm}^{2}\right)$. Administration of the highest dose of

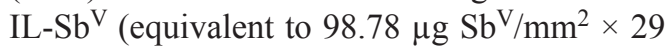
daily, and $2864.6 \mu \mathrm{g} \mathrm{SbV} / \mathrm{mm}^{2}$ in total) was effective in $4 / 6$ and $2 / 6$ mice infected with 
L. (V.) panamensis and $L$. (V.) braziliensis at 60 days pt.

Some positive results were obtained with IL-Sb ${ }^{\mathrm{V}}$ in a hamster CL model $(100 \%$ lesion reduction and no parasites in organs) (Travi, et al., 1993; Yépez, et al.,1999); however, no complete cure of CL-infected mice has been documented. Per example, treatment of mice infected with $L$. (L.) amazonensis, with IL-SbV $28 \mathrm{mg} / \mathrm{kg} /$ day $\times 5$, every 4-5 days resulted in partial parasite burden reduction with no increase in footpad thickness, but not in cure (Cos et al., 2018; Fournet et al., 1996). Differences in numbers of $\mathrm{Sb}^{\mathrm{V}}$-IL sessions, dose, site of infection, parasite species, and followup time could explain the different results obtained in this study. In addition, type of CL lesion could be also involved; ulcerated lesions (Fig. 1, Fig. 2) without parasite dissemination or spontaneous cure are characteristic of our CL-mouse model (Neira, et al., 2019b). The final $\mathrm{Sb}^{\mathrm{V}}$ doses/per mouse (at a body weight, $27 \mathrm{~g}$ ) also differed. At 150, 50, and $16.6 \mathrm{mg} /$ $\mathrm{kg}$ /day $\times 29$, the final doses were $117.5,39.2$ and $13.9 \mathrm{mg} \mathrm{Sb}$, while at $28 \mathrm{mg} / \mathrm{kg} \times 5$ the dose was $3.78 \mathrm{mg} 224 \mathrm{Sb}^{\mathrm{V}}$ (almost three times less than the minimum non-effective dose used in our study).

IL-Sb ${ }^{\mathrm{V}}$ treatment induced a dose-response effect; drug potency was higher soon after treatment than at the end of experiment, as $\mathrm{ED}_{50}$ values were lower at 15 than 60 days pt. Hence, the maximal $\mathrm{Sb}^{\mathrm{V}}$ concentration used may have been unable to kill $100 \%$ of parasites on all treated mice, with remaining parasites able to reactivate lesions, as was observed in some mice at the end of the experiment. In a previous study we reported the histopathological characteristics of CL lesions before treatment (Neira et al., 2019b). They were characterized moderate hyperkeratosis and acanthosis, mild spongiosis in the epidermis, with a severe diffuse inflammatory infiltrate predominantly comprised of lymphocytes and plasma cells, and abundant amastigote-infected macrophages in the dermis. It is possible that a higher $\mathrm{mgSb}^{\mathrm{V}} / \mathrm{kg}$ dose will be necessary to kill all parasites.
Next, we decided to evaluate $\mathrm{Sb}^{\mathrm{V}}$ activity in vitro on promastigotes, axenic amastigotes, and intracellular amastigotes of both Leishmania strains infecting THP-1 cells, using the same batch as that used for in vivo experiments. Unfortunately, we were unable to calculate $\mathrm{IC}_{50}$ values (drug potency) at the maximal doses evaluated in any of the live parasite forms of either parasite species. The antileishmanial activities of $\mathrm{Sb}^{\mathrm{V}}$ have been demonstrated in various in vitro models, showing some peculiarities compared with other drugs such as miltefosine or pentamidine isethionate (Fernández et al., 2014). Most notably, $\mathrm{Sb}^{\mathrm{V}}$ is unable to kill promastigotes and, to a lesser extent, axenic amastigotes (Sereno et al., 1998); however, activities have been demonstrated against intracellular amastigotes infecting different types of macrophage and reference strains or isolates collected worldwide $\left(\mathrm{IC}_{50} 2.9-146 \mu \mathrm{gSb} / \mathrm{ml}\right)$ (Fernández et al., 2014; Pérez-Franco et al., 2016). In general, drug susceptibility (in vitro) is supposed as a method to predict treatment outcome. However, this was not our case as $\mathrm{Sb}^{\mathrm{V}}$ was active on some CL infected mice but not on free or intracellular parasites life forms. Both reference strains used are not classified as $\mathrm{Sb}$-resistant strains. In contrast, $\mathrm{Sb}^{\mathrm{V}}$ activity has been demonstrated against $L$. (V.) braziliensis /M2903 intracellular amastigotes infecting U937 differentiated cells ( $\mathrm{IC}_{50}$ 26-50 $\mu \mathrm{gSb}^{\mathrm{V}} / \mathrm{ml}$ ) (Pérez-Franco et al., 2016). Before our experiments, the parasites had never been exposed to antimonials in neither in vitro or in vivo assays; however, they have been cultivated in vitro for a relatively extended period, by quarterly passage in BALB/mice. Leishmania resistance mechanisms or other factors related to drug (drug quality, intrinsic drug properties, drug physicochemical characteristics), parasite (lower intrinsic susceptibility to the drug, parasite infection by RNA viruses, parasite adaptations, manipulation skills of the parasites, higher parasite fitness) or host (immunological factors, pharmacokinetics, genetics) could be involved with $\mathrm{Sb}^{\mathrm{V}}$ treatment efficacy or failure (Vanaerschot et al. 2014). 
Independent of the lack of in vitro $\mathrm{Sb}^{\mathrm{V}}$ response, the use of intralesional $\mathrm{Sb}^{\mathrm{V}}$ with a dose calculated as $\mathrm{mg} / \mathrm{kg}$ body weight and administered over a large number of IL-sessions, with small injection volumes each day could be effective against $L$. (V.) panamensis and $L$. (V.) braziliensis-CL infection. An appropriate $\mathrm{Sb}^{\mathrm{V}}$-dose (higher than $150 \mathrm{mg} / \mathrm{kg}$ /day x 20) must be evaluated.

Ethical statement: the authors declare that they all agree with this publication and made significant contributions; that there is no conflict of interest of any kind; and that we followed all pertinent ethical and legal procedures and requirements. All financial sources are fully and clearly stated in the acknowledgements section. A signed document has been filed in the journal archives.

See Digital Appendix at: revistas.ucr.ac.cr

\section{ACKNOWLEDGMENTS}

This work was supported by the Autonomous Patrimony of the National Financing Fund for Science, Technology, and Innovation Francisco José de Caldas, Contract RC-6872014. AMV was sponsored by the program High-Level of Human Capital Training for the Regions-Santander Department, announcement 771 of 2016, Minciencias and the Government of Santander (Colombia).

\section{RESUMEN}

\section{Actividad antileishmania de 29 sesiones diarias de antimonio pentavalente intralesional en ratones BALB/c infectados con Leishmania (Viannia)}

Introducción: Los antimoniales pentavalentes aplicados intralesionalmente (IL-SbV ${ }^{\vee}$ se recomiendan para el tratamiento de la leishmaniasis cutánea (LC) simple. Se recomiendan pocas sesiones (1-5) y volúmenes (1-5 ml cada uno) en relación con el tamaño de la lesión (LS). No existe un protocolo de IL-Sb ${ }^{\mathrm{V}}$ validado que utilice dosis calculadas según el peso corporal (en $\mathrm{mg} / \mathrm{kg}$ ) y administradas durante varias sesiones en pocos volúmenes de inyección.
Objetivo: El objetivo del estudio fue determinar la eficacia de diferentes concentraciones de $\mathrm{IL}-\mathrm{Sb}^{\mathrm{V}}$ administradas en 29 sesiones diarias de $100 \mu \mathrm{L}$ cada una, en ratones con LC. Métodos: Ratones infectados con $L$. $(V$.) panamensis y $L$. (V) braziliensis $(\mathrm{N}=6)$ fueron tratados intralesionalmente con 150,50 y $16,6 \mathrm{mg} \mathrm{Sb}{ }^{\mathrm{V}} / \mathrm{kg} /$ día x 29 días. Se determinó el porcentaje de reducción del área de la lesión, la eficacia estética y final (sin lesiones, sin parásitos) y la dosis efectiva $(\mathrm{DE})_{50}$. Adicionalmente de evaluó la actividad in vitro del $\mathrm{Sb}^{\mathrm{V}}$.

Resultados: Los valores de $\mathrm{DE}_{50}$ fueron 72.2 y 66.3 (al final del tratamiento), 54.3 y 37.7 (15 días pt) y 145.3 y 148.6 (60 días pt) para cada especie. Se encontraron diferencias entre las especies sólo a los 15 días pt. La eficacia del tratamiento IL-SbV $-150 \mathrm{mg}, 60$ días pt., fue de 66.6 y $33.3 \%$ en ratones infectados con $L$. (V.) panamensis $L$. (V.) braziliensis respectivamente. Después de 15 días pt., se observó reactivación de la lesión en algunos ratones "estéticamente curados". Glucantime no fue activo in vitro. Conclusiones: El uso intralesional de $\mathrm{Sb}^{\mathrm{V}}$ con una dosis calculada en $\mathrm{mg} / \mathrm{kg}$ de peso corporal y administrada durante varias sesiones, con pequeños volúmenes de inyección cada día, podría ser eficaz en LC por $L$. (V.) panamensis y L. (V.) braziliensis. Dosis adecuadas de $\mathrm{Sb}^{\mathrm{V}}$ (superiores a $150 \mathrm{mg} / \mathrm{kg} /$ día x 20) deben evaluarse.

Palabras clave: Glucantime; leishmaniasis cutánea del Nuevo Mundo; medicamento intralesional; Leishmania panamensis; Leishmania braziliensis.

\section{REFERENCES}

Bailey, F., Mondragon-Shem, K., Hotez, P., Ruiz-Postigo, J. A., Al-Salem, W., Acosta-Serrano, Á., \& Molyneux, D. H. (2017). A new perspective on cutaneous leishmaniasis-Implications for global prevalence and burden of disease estimates. PloS Neglected Tropical Diseases, 11(8), e0005739.

Burza, S., Croft, S. L., \& Boelaert, M. (2018). Leishmaniasis. The Lancet, 392(10151), 951-970.

Castro, M., Cossio, A., Velasco, C., \& Osorio, L. (2017). Risk factors for therapeutic failure to meglumine antimoniate and miltefosine in adults and children with cutaneous leishmaniasis in Colombia: A cohort study. PloS Neglected Tropical Diseases, 11(4), e0005515.

Cos, P., Janssens, J., Piñón, A., Cuesta-Rubio, O., YglesiasRivera, A., Díaz-García, A., Vilegas, W., \& Monzote, L. (2018). Efficacy of four Solanum spp. extracts in an animal model of cutaneous leishmaniasis. Medicines, 5(2), 49.

de Oliveira Duque, M. C., Quintão Silva, J. J., Soares, P., Magalhães, R. S., Horta, A., Paes, L., Rosandiski Lyra, M., Pimentel, M., de Fátima Antonio, L., de Camargo Ferreira, E., Vasconcellos, É., Saheki, M. N., de Almeida Marzochi, M. C., Valete-Rosalino, C. 
M., \& de Oliveira Schubach, A. (2019). Comparison between systemic and intralesional meglumine antimoniate therapy in a primary health care unit. Acta Tropica, 193, 176-182.

Fernández, O. L., Diaz-Toro, Y., Ovalle, C., Valderrama, L., Muvdi, S., Rodríguez, I., Gomez, M. A., \& Saravia, N. G. (2014). Miltefosine and antimonial drug susceptibility of Leishmania Viannia species and populations in regions of high transmission in Colombia. PloS Neglected Tropical Diseases, 8(5), e2871.

Fournet, A., Ferreira, M. E., Rojas De Arias, A., Torres De Ortiz, S., Fuentes, S., Nakayama, H., Schinini, A., \& Hocquemiller, R. (1996). In vivo efficacy of oral and intralesional administration of 2-substituted quinolines in experimental treatment of new world cutaneous leishmaniasis caused by Leishmania amazonensis. Antimicrobial Agents and Chemotherapy, 40(11), 2447-2451.

Goto, H., \& Lindoso, J. A. (2010). Current diagnosis and treatment of cutaneous and mucocutaneous leishmaniasis. Expert Review of Anti-Infective Therapy, 8(4), 419-433.

Gupta, N., Goyal, N., \& Rastogi, A. (2001). In vitro cultivation and characterization of axenic amastigotes of Leishmania. Trends in Parasitology, 17(3), 150-153.

Neira, L. F., Mantilla, J. C., \& Escobar, P. (2019a). Antileishmanial activity of a topical miltefosine gel in experimental models of New World cutaneous leishmaniasis. Journal of Antimicrobial Chemotherapy, 74(6), 1634-1641

Neira, L. F., Peña, D. P., Vera, A. M., Mantilla, J. C., \& Escobar, P. (2019b). Leishmaniasis cutánea inducida por especies de Leishmania Viannia en ratones BALB/c y eficacia de un tratamiento tópico. Revista Universidad Industrial de Santander, 51, 33-42.

Oliveira-Neto, M. P., Schubach, A., Mattos, M., da Costa, S. C., \& Pirmez, C. (1997). Intralesional therapy of American cutaneous leishmaniasis with pentavalent antimony in Rio de Janeiro, Brazil- an area of Leishmania (V.) braziliensis transmission. International Journal of Dermatology, 36(6), 463-468.
Pan American Health Organization (PAHO). (2018). Leishmaniasis in the Americas: Treatment recommendations. https://iris.paho.org/handle/10665.2/7704

Pérez-Franco, J. E., Cruz-Barrera, M. L., Robayo, M. L., López, M. C., Daza, C. D., Bedoya, A., Mariño, M. L., Saavedra, C. H., \& Echeverry, M. C. (2016). Clinical and parasitological features of patients with American cutaneous leishmaniasis that did not respond to treatment with meglumine antimoniate. PloS Neglected Tropical Diseases, 10(5), e0004739.

Sereno, D., Cavaleyra, M., Zemzoumi, K., Maquaire, S., Ouaissi, A., \& Lemesre, J. L. (1998). Axenically grown amastigotes of Leishmania infantum used as an in vitro model to investigate the pentavalent antimony mode of action. Antimicrobial Agents and Chemotherapy, 42(12), 3097-3102.

Soto, J., Paz, D., Rivero, D., Soto, P., Quispe, J., Toledo, J., \& Berman, J. (2016). Intralesional pentamidine: a novel therapy for single lesions of Bolivian cutaneous leishmaniasis. The American Journal of Tropical Medicine and Hygiene, 94(4), 852-856.

Sundar, S., More, D. K., Singh, M. K., Singh, V. P., Sharma, S., Makharia, A., Kumar, P. C., \& Murray, H. W. (2000). Failure of pentavalent antimony in visceral leishmaniasis in India: report from the center of the Indian epidemic. Clinical Infectious Diseases, 31(4), 1104-1107.

Travi, B. L., Martinez, J. E., \& Zea, A. (1993). Antimonial treatment of hamsters infected with Leishmania (Viannia) panamensis: assessment of parasitological cure with different therapeutic schedules. Transactions of the Royal Society of Tropical Medicine and Hygiene, 87(5), 567-569.

Vanaerschot, M., Dumetz, F., Roy, S., Ponte-Sucre, A., Arevalo, J., \& Dujardin, J. C. (2014). Treatment failure in leishmaniasis: drug-resistance or another (epi-) phenotype? Expert Review of Anti-Infective Therapy, 12(8), 937-946.

Yépez, J., Cazorla, D., Añez, N., \& Yarbuh, A. L. (1999). Effect of intralesional treatment with lidocaine and glucantime in hamsters infected with Leishmania (Viannia) braziliensis. Boletín de la Dirección de Malariol Saneamiento Ambiental, 39, 10-20. 